\title{
The association between mitochondrial genetic variation and reduced colony fitness in an invasive wasp
}

\author{
Jana Dobelmann ${ }^{1}$ (D) | Alana Alexander ${ }^{2}$ (D) | James W. Baty ${ }^{1}$ (D) | Neil J. Gemmell ${ }^{2}$ \\ Monica A. M. Gruber ${ }^{1}$ (D) | Oliver Quinn ${ }^{1}$ (D) | Tom Wenseleers ${ }^{3}$ (D) | Philip J. Lester ${ }^{1}$ (D)
}

${ }^{1}$ School of Biological Sciences, Victoria University of Wellington, Wellington, New Zealand

${ }^{2}$ Department of Anatomy, University of Otago, Dunedin, New Zealand

${ }^{3}$ Department of Biology, Katholieke Universiteit Leuven, Leuven, Belgium

Correspondence

Jana Dobelmann, School of Biological Sciences, Victoria University of Wellington, Wellington, New Zealand.

Email: jana.dobelmann@vuw.ac.nz

Funding information

Ministry of Business, Innovation and Employment, Grant/Award Number: C09X1501; Royal Society of New Zealand, Grant/Award Number: 13-VUW-037

\begin{abstract}
Despite the mitochondrion's long-recognized role in energy production, mitochondrial DNA (mtDNA) variation commonly found in natural populations was assumed to be effectively neutral. However, variation in mtDNA has now been increasingly linked to phenotypic variation in life history traits and fitness. We examined whether the relative fitness in native and invasive common wasp (Vespula vulgaris) populations in Belgium and New Zealand (NZ), respectively, can be linked to mtDNA variation. Social wasp colonies in NZ were smaller with comparatively fewer queen cells, indicating a reduced relative fitness in the invaded range. Interestingly, queen cells in this population were significantly larger leading to larger queen offspring. By sequencing $1,872 \mathrm{bp}$ of the mitochondrial genome, we determined mitochondrial haplotypes and detected reduced genetic diversity in NZ. Three common haplotypes in NZ frequently produced many queens, whereas the four rare haplotypes produced significantly fewer or no queens. The entire mitochondrial genome for each of these haplotypes was sequenced to identify polymorphisms associated with fitness reduction. We found 16 variable sites; however, no nonsynonymous mutation that was clearly causing impaired mitochondrial function was detected. We discuss how detected variants may alter secondary structures, gene expression or mito-nuclear interactions, or could be associated with nuclear-encoded variation. Whatever the ultimate mechanism, we show reduced fitness and mtDNA variation in an invasive wasp population as well as specific mtDNA variants associated with fitness variation within this population. Ours is one of only a few studies that confirm fitness impacts of mtDNA variation in wild nonmodel populations.
\end{abstract}

\section{KEYWORDS}

colony fitness, invasive species, mitochondrial DNA, mtDNA variation, Vespula vulgaris

\section{1 | INTRODUCTION}

Mitochondria play a central role in energy metabolism. Despite this, mitochondrial DNA (mtDNA) variation was mostly thought to approximate neutrality and used as neutral marker for decades (Ballard, Pichaud, \& Fox, 2014). However, variation in mitochondrial genes is increasingly recognized as subject to selection on phenotypic variation in life history traits, including effects on ageing, reproduction and energy metabolism (Ballard et al., 2014; Camus, Wolf, Morrow, \& Dowling, 2015; Dowling, Friberg, \& Lindell, 2008). Accumulating evidence also suggests that mitochondrially encoded fitness effects can be caused by mutations as small as 
single base pair substitutions (Camus, Clancy, \& Dowling, 2012; Clancy, 2008; Patel et al., 2016; Xu, 2008; Yee, Sutton, \& Dowling, 2013). Nonsynonymous single nucleotide polymorphisms (SNPs) can cause drastic reductions in sperm number and decrease fertility and lifespan (Clancy, 2008; Patel et al., 2016; Xu, 2008; Yee et al., 2013) with potential negative effects on population viability (Gemmell, Metcalf, \& Allendorf, 2004; Wolff, Gemmell, Tompkins, \& Dowling, 2017). Most of these polymorphisms have been observed in Drosophila fruit flies where divergent mtDNA haplotypes have been tested against a controlled nuclear background (Camus et al., 2012; Yee et al., 2013). Several studies suggest that even apparently synonymous polymorphisms can affect haplotype energy metabolism without altering the protein sequence (Camus et al., 2015; Camus, Wolff, Sgro, \& Dowling, 2017).

Outside of the laboratory, there is accumulating evidence of the importance of mitochondrial variants on reproductive traits (Smith, Turbill, \& Suchentrunk, 2010), local adaptation (Lamb et al., 2018), phylogeographic population structure and differentiation, (Morales, Sunnucks, Joseph, \& Pavlova, 2017), the fitness of hybrids (Ellison \& Burton, 2006) and thus the stability of hybrid zones (Blier, Dufresne, $\&$ Burton, 2001), and perhaps even speciation (Gershoni, Templeton, \& Mishmar, 2009; Hill, 2019). Therefore, the mitochondrial genetic variation found in wild populations (Dowling et al., 2008) should have strong implications for organismal fitness. Few currently available studies provide evidence for functional differences among mitochondrial haplotypes in the field and in nonmodel organisms (Blier et al., 2001; Ellison \& Burton, 2006; Flight, Nacci, Champlin, Whitehead, \& Rand, 2011; Schwartz, Arendsee, \& Bronikowski, 2015; Smith et al., 2010). Most mtDNA polymorphisms are assumed to be caused by an accumulation of slightly deleterious mutations facilitated by genetic drift and week purifying selection (Rand \& Kann, 1996). Yet, how these polymorphisms affect fitness remains unclear. Seeking evidence of functional differences among mtDNA variants is required to improve understanding of associations between mtDNA variation and fitness.

Species introductions provide an interesting opportunity to examine mitochondrial fitness effects in wild populations, as mitochondrial haplotypes are expressed in a new environment with a potentially different climate and diet (Ballard et al., 2014), and are subject to the founder effect where a subset of individuals initiates a new population leading to a reduction in mtDNA diversity (Nei, Maruyama, \& Chakraborty, 1975). This genetic bottleneck can be beneficial for removing harmful alleles segregating in the source population (Garnas et al., 2016). However, a small initial population size may also increase the frequencies of deleterious variants through genetic drift overriding selection and may lead to deleterious mtDNA variants becoming more abundant in the new population (Marsden et al., 2016). Under these circumstances, a founder population experiences reduced adaptive potential and is at an increased risk for fitness declines (Bock et al., 2015). Genetic drift and rapid growth of expanding populations can lead to the accumulation of deleterious mutations, which may persist for many generations after range expansion (Peischl, Dupanloup, Kirkpatrick, \& Excoffier,
2013) making deleterious mtDNA variants that affect fitness potentially more common in invasive populations.

A group that is globally successful at such species invasions are social insects (Lowe, Browne, Boudjelas, \& De Poorter, 2000; Moller, 1996). Very few or possibly only one inseminated female can found a new population and lead to low mtDNA haplotype diversity in the new population (Arca et al., 2015; Lester et al., 2014; Moller, 1996). The mtDNA bottleneck and social structure that leads to a small effective population size makes social insects more vulnerable to genetic or demographic changes than solitary species (Chapman \& Bourke, 2001; Pamilo, Gertsch, Thorén, \& Seppä, 1997). This makes social insects a particularly interesting system for examining the impact of species introductions on fitness associated with mtDNA variation.

The eusocial common wasp (Vespula vulgaris) is a successful invading social insect. Native to Eurasia, the species has been accidently introduced to New Zealand (Donovan, 1984), Australia (Matthews, Goodisman, Austin, \& Bashford, 2000) and South America (Carcamo et al., 2016; Masciocchi \& Corley, 2013). In New Zealand, extremely high densities of up to 40 common wasp nests per hectare can be found in the Fuscospora beech forests of its South Island (Beggs et al., 1998; Lester, Haywood, Archer, \& Shortall, 2017). In comparison, the highest density of wasp nests found over 22 years of observation in England, part of the common wasp's native range, was approximately 1.8 nests per hectare (Archer, 2001). Vespula wasps, including the common wasp, have become a major pest in New Zealand, causing NZ\$133 million in damages every year across the apiculture and livestock farming industries (Maclntyre \& Hellstrom, 2015), devastating terrestrial invertebrate communities, and harming native biota (Elliott, Wilson, Taylor, \& Beggs, 2010; Lester \& Beggs, 2019; Toft \& Rees, 1998). Studying mitochondrial genetic variation in common wasps could aid in understanding fitness variation in this and other invasive species.

In this study, we tested whether fitness variation in the native and introduced range of the common wasp is associated with mtDNA variation. Initially, we measured fitness indicators, for example nest size and new queen output, of wasp colonies. Next, we looked at mitochondrial genetic variation and defined haplotypes in both populations by sequencing $C y t B$ and a fragment from Cox 1 to Cox2, spanning intergenic region between the genes. We expected to find reduced mtDNA haplotype diversity in the invaded range of New Zealand caused by the introduction bottleneck. This is important as variation in these genes and in the intergenic region has been previously associated with fitness effects in other insect species (Clancy, 2008; Johnson, Schmid-Hempel, \& Schmid-Hempel, 2011; Patel et al., 2016). We then examined associations between fitness traits and mitochondrial haplotypes using generalized mixed models. Lastly, in the search for mutations that could lead to reduced mitochondrial function and affect relative fitness, we sequenced the entire mitochondrial genome of a subset of common wasp samples. Naturally occurring mitochondrial haplotypes in these wasps may show variation that could help in understanding the role of mtDNA in phenotype fitness of invasive species. 


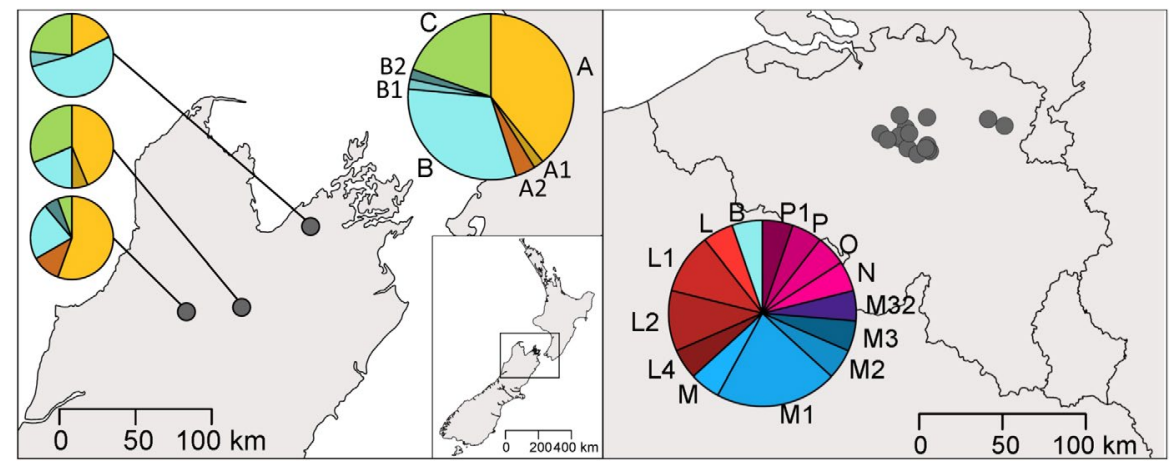

FIGURE 1 Sampling locations and haplotype frequencies in New Zealand and Belgium. Left: Points show sampling sites Braeburn, Six Mile and Tin Line (left to right), in Fuscospora beech forest in Nelson Lakes National Park in Saint Arnaud, New Zealand. Pie charts (left) show haplotypes detected in each site, and a summary pie chart (top right) combines all New Zealand samples $(n=51)$. Right: Points show nest locations in Leuven. Pie chart shows the haplotypes detected in these samples $(n=19)$. Maps were made using the MAPs package (Minka \& Deckmyn, 2016) in R [Colour figure can be viewed at wileyonlinelibrary.com]

\section{2 | MATERIALS AND METHODS}

\section{1 | Sampling}

Whole Vespula vulgaris nests were collected in Belgium and New Zealand in early autumn (September and March, respectively) from 2014 to 2016 . The climate at both sampling locations is similar with mean annual temperatures around $10^{\circ} \mathrm{C}$, but higher annual rainfall in New Zealand (Table S1). In the invaded range of New Zealand, 62 nests (18 in 2014, 25 in 2015 and 19 in 2016) were sampled from a high-density wasp population in a Fuscospora beech forest in Nelson Lakes National Park, near Saint Arnaud using three collection sites (Six Mile: $41.769^{\circ} \mathrm{S} ; 172.957^{\circ} \mathrm{E}$, Braeburn: $41.795^{\circ} \mathrm{S} ; 172.516^{\circ} \mathrm{E}$ and Tin Line: $41.281^{\circ} \mathrm{S} ; 173.509^{\circ} \mathrm{E}$; Figure 1). Each year, nests were collected within 3 days at the end of the wasp season. Nests were found in the ground, among tree roots, or in tree trunks near the ground by observing foraging workers returning to the nest entrance. Before carefully extracting each nest, we anaesthetized the wasps using diethyl ether poured into the entrance through a flexible $15-\mathrm{cm}$-long plastic tube. Excavated nests were placed in buckets while in the field and chilled for approximately $2 \mathrm{hr}$ before handling. The wasps were alive and could be handled safely after chilling.

In Belgium, 32 nests (12 in 2014, 6 in 2015 and 14 in 2016) were collected around Leuven $\left(50.879^{\circ} \mathrm{N} ; 4.702^{\circ} \mathrm{E}\right.$; Figure 1). Wasp densities in Belgium were lower and therefore nests were more difficult to find than in New Zealand. The local community and the fire brigade provided information about nests. All nests were collected within 3 weeks at the end of each wasp season. Nest locations were in or near the ground, among shrubs and roots, or in artificial structures like wall cavities, compost heaps, or hanging in garden houses and attics. Without anaesthesia, whole nests were excavated and transferred into sealed buckets. In Belgium, we used $\mathrm{CO}_{2}$ to anaesthetize wasps before collecting live wasps from the nests. A subset of five wasps were taken from each nest in both New Zealand and Belgium for genetic analyses and snap frozen in a liquid nitrogen dry shipper at $-196^{\circ} \mathrm{C}$.

\subsection{Colony fitness analysis}

To assess colony size and relative reproductive output, we removed the nest paper, separated combs and placed them flat on a table to photograph the cells and combs (Figure 2). Common wasp nests are initiated by a single inseminated queen (Matsuura \& Yamane, 1990). This queen invests in colony growth by producing workers until autumn, when resources are allocated towards reproduction and new queens and males are produced (Johnson et al., 2009; Matsuura \& Yamane, 1990). Workers in this wasp species are highly effective in removing worker laid eggs, which would develop into males, so that the queen maintains a reproductive monopoly (Foster \& Ratnieks, 2001). Larger cells, specifically built for queen rearing (queen cells), can be easily distinguished from the small cells (worker cells) used to rear multiple generations of workers and the majority of males (Spradbery, 1971). Although numbers of queens and males produced are overall equal, investment in new queens is generally considered to be larger as queens have approximately 1.6 times the dry mass of males (Archer, 1980, 1998). The number of queen cells depends on the adult female worker force, which can be indirectly measured from the number of worker cells previously constructed (Spradbery, 1971), and can be used as an estimate of colony fitness. Using ImageJ2 software (Schindelin, Rueden, Hiner, \& Eliceiri, 2015), the sizes of a minimum of 10 queen and 10 worker cells were measured from digital photographs from every nest to calculate mean queen and worker cell size. When worker cell size differed among combs within a nest, cell numbers were calculated separately for each comb. The total area of the respective cell type was then measured and used to estimate the number of queen and worker cells per nest.

We tested for differences between New Zealand and Belgium in the proportion of queen cell producing colonies using Pearson's chi-squared test and used $t$ tests to compare cell sizes and numbers between nests sampled in New Zealand and Belgium. Within these two populations, the correlation of queen and worker cells was analysed using a Pearson's correlation test. Linear regression models of queen cell production were built using the Im function in R v3.3.2 ( $R$ Core Team, 2014) to calculate the efficiency of queen cell production. 


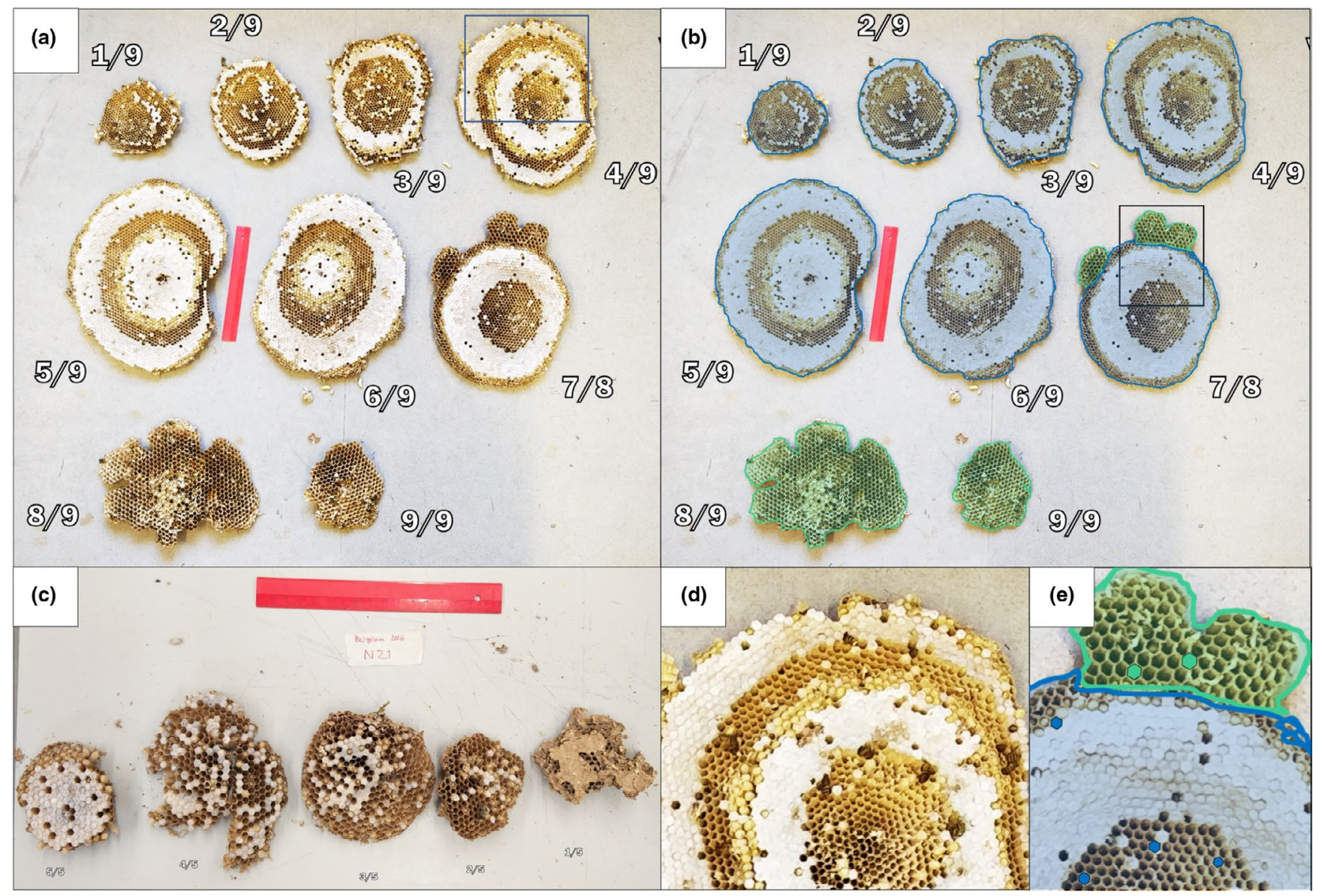

FIGURE 2 Nest analysis. (a) Large nest with approx. 12,700 cells, including regular brood pattern and queen cells (see d and e). The first comb (1/9) is at the top and the nest extended downwards (through 9/9). (b) Exemplary analysis: worker cell area shaded in blue and queen cell area green. (c) Small nest with approx. 1,400 cells. No queen cells and irregular brood pattern are present. (d) Zoom on comb 4 from panel a: concentric rings of white-capped brood with uncapped cells containing eggs or larvae and some empty cells in between. (e) Zoom on comb 7 from panel b: hexagons show the difference in worker (bottom) and queen (top) cell size. Red scale in a, b and c is $17 \mathrm{~cm}$ [Colour figure can be viewed at wileyonlinelibrary.com]

Because collections in Belgium were spread out over 3 weeks, we used Spearman's correlation to test whether collection date affected the worker and queen cell number of mature colonies (with both cell types). Boxplots and correlation plots were made using the GGPLOT2 package (Wickham, 2016), and multiple plots were arranged with the GRIDEXTRA package (Auguie, 2016).

\section{3 | DNA extraction}

DNA was extracted from pools of five wasps per nest due to the expectation that all individuals would carry the same mtDNA as the nest queen. Wasps were homogenized in GENEzol reagent (Geneaid) containing $\beta$-mercaptoethanol using a bead beater (MiniBeadbeater-16, BioSpec). DNA was then purified using phenol/chloroform or by using the viral RNA/DNA isolation kit (Macherey-Nagel) in a King Fisher ${ }^{\mathrm{TM}}$ Flex Purification System (Thermo Fisher Scientific). Kit-extracted DNA was isolated from residual salt precipitate by incubation at $65^{\circ} \mathrm{C}$ for 3 min followed by centrifugation for $1 \mathrm{~min}$ $30 \mathrm{~s}$ at $15,340 \times \mathrm{g}$. DNA quality and concentration were determined using a ND-1000 Spectrophotometer (NanoDrop).

\subsection{Mitochondrial DNA PCR and Sanger sequencing}

We used PCR to amplify the mtDNA genes CytB, Cox1, Cox2 and the intergenic region between Cox 1 and Cox 2 that contains tRNALeu (hereafter referred to as tLeu + Cox2) from 51 nests from New Zealand and 19 from Belgium. Primers for CytB were taken from Simon et al. (1994). Primers for Cox1 and tLeu + Cox2 were designed using the NCBI Primer-BLAST algorithm (https://www.ncbi. nlm.nih.gov/tools/primer-blast) with the mitochondrial genome of a related wasp species, Vespula germanica (GenBank Accession no. KR703583), as a reference. Primer sequences and annealing temperatures are shown in Table 1. PCR mixes consisted of 150$500 \mathrm{ng}$ template DNA, $1 \times$ PCR buffer, $1.5 \mathrm{mM} \mathrm{MgCl}_{2}, 200 \mu \mathrm{M}$ of each dNTP, $0.4 \mu \mathrm{M}$ each of forward and reverse primer, and 0.5 units of Taq DNA polymerase (Invitrogen, Thermo Fisher Scientific). Cycling conditions were $3 \mathrm{~min}$ at $94^{\circ} \mathrm{C}, 30$ cycles of $45 \mathrm{~s}$ at $94^{\circ} \mathrm{C}$, $30 \mathrm{~s}$ variable annealing temperatures (Table 1 ) and $55 \mathrm{~s}$ at $72^{\circ} \mathrm{C}$, followed by $10 \mathrm{~min}$ at $72^{\circ} \mathrm{C}$. Before sequencing, PCR products were purified using ExoSAP-IT (Affymetrix, Thermo Fisher Scientific). 
TABLE 1 Primers used in PCR and sequencing reactions

\begin{tabular}{|c|c|c|c|c|c|}
\hline Target gene & Primer name & Sequence $5^{\prime}-3^{\prime}$ & Amplicon (bp) & Annealing temp. $\left({ }^{\circ} \mathrm{C}\right)$ & Reference \\
\hline tLeu + Cox2 & $\begin{array}{l}\text { Vg tLeu F } \\
\text { Vg tLeu R }\end{array}$ & $\begin{array}{l}\text { ATCTGGTTTTCCTCGACGATACT } \\
\text { TACGTCCAGGGGTAGCATCA }\end{array}$ & 854 & 50.0 & \\
\hline Set B & $\begin{array}{l}V \vee m t D N A-B F \\
V v \text { mtDNA-B R }\end{array}$ & $\begin{array}{l}\text { AGTTTTCCTACCAACCCCTGT } \\
\text { AGGGAATCAGTGAATAAATCCTGC }\end{array}$ & 11,202 & 63.0 & \\
\hline
\end{tabular}

Note: Primers were designed to target cytochrome b (CytB), cytochrome c oxidase subunit I (Cox1) and the intergenic region including tRNA leucine to cytochrome c oxidase subunit II (tLeu + Cox2). Forward primer given first, then reverse primer. Primer sets A and B were used to cover the whole mitochondrial genome in the long-range PCR for next-generation sequencing. Primer positions are shown in Figure 5.

Sequencing in both directions was carried out by the Genetic Analysis Service at the University of Otago, Dunedin, New Zealand. Forward and reverse sequences were aligned using the ClustalW algorithm (Thompson, Higgins, \& Gibson, 1994), lowquality ends were manually trimmed, and the Cox1 and tLeu + Cox2 sequences that overlapped were assembled in GENEIOUS v8.0.5 (Kearse et al., 2012). To confirm sequence authenticity, the sequences were verified using a NCBI BLASTn search (http://blast. ncbi.nlm.nih.gov/). Sequences generated in this study have been deposited in GenBank (Accession nos. MK967473-MK967508). To assess amino acid variation, sequences were translated into protein sequences by using the $V$. germanica mitochondrial genome (KR703583) as a reference for annotation. To find the best model for molecular evolution, we used Bayesian information criterion (BIC) scores in MEGA v7.0.18 (Kumar, Stecher, \& Tamura, 2016). Then, for every gene, Tajima's neutrality test was performed to test deviations from expectations of neutral selection (Tajima, 1989).

\section{5 | Genetic variation and population structure}

To analyse haplotype fitness associations, the three PCR amplicons for CytB, Cox1 and tLeu + Cox2 (1,872 bp) were concatenated. Number of haplotypes, haplotype diversity and nucleotide diversity were generated using DNASP v5.10.01 (Librado \& Rozas, 2009). We determined whether the sample size represents the diversity of haplotypes in the two populations by generating rarefaction curves using the VEGAN package and rarefaction.txt function (Jacobs, 2011; Oksanen et al., 2017) in R. To analyse population structure and examine whether genetic diversity was partitioned among or within populations, an analysis of molecular variance (AMOVA) was conducted in GenALEx (v6.503) using F-statistics with 1,000 permutations (Peakall \& Smouse, 2012). We finally used TempNet (Prost \& Anderson, 2011) to construct a structured haplotype network with populations as layers, allowing visualization of the relationships within and among the two populations.

\subsection{Whole mitochondrial genome Illumina sequencing}

A subset of ten samples from New Zealand were chosen for whole mitochondrial genome sequencing. This subset included two samples each from haplotypes $A, B, C$, and $A 2$, and one sample each for $A 1$ and B1. For each sample, we prepared two long-range PCRs to cover the entire mitochondrial genome in two fragments, using primer set A and B (Table 1). PCR mixes contained 50 ng DNA, $0.5 \mu \mathrm{M}$ each of forward and reverse primers, and Platinum SuperFi PCR Master Mix (Thermo Fisher Scientific) to $50 \mu$ l total reaction volume. Long-range PCR conditions were as follows: $95^{\circ} \mathrm{C}, 3 \mathrm{~min}$; 35 cycles of $95^{\circ} \mathrm{C}$ for $20 \mathrm{~s}, 63.4^{\circ} \mathrm{C}$ (set A) or $63.0^{\circ} \mathrm{C}$ (set B) for $15 \mathrm{~s}, 68^{\circ} \mathrm{C}$ for $8 \mathrm{~min}$ (set A) or $16 \mathrm{~min}$ (set B); with a final extension of $68^{\circ} \mathrm{C}$ for $10 \mathrm{~min}$. Products were resolved by electrophoresis in $0.7 \%(\mathrm{w} / \mathrm{v})$ agarose gel to confirm positive amplification. DNA Clean and Concentrator columns (Zymo Research) were used to purify the PCR products and elute them into $\mathrm{H}_{2} \mathrm{O}$. DNA concentrations were measured using a Quantus Fluorometer (Promega). From both products ( $A$ and $B$ ), $800 \mathrm{ng}$ of DNA each was combined and delivered to Annoroad Gene Technology for library construction and sequencing. Libraries were constructed using NEBNext Ultra II DNA Library Prep Kits for Illumina (New England Biolabs). Sequencing was conducted on an Illumina HiSeq platform using 150 paired-end reads. The insert fragment range was $200-400$ bp (peak at $350 \mathrm{bp}$ ).

\subsection{Whole mitochondrial genome assembly and variant identification}

We used the V. germanica mitochondrial genome as a reference because this is the first study to sequence the whole mitochondrial genome of V. vulgaris. We carried out a reference-based assembly for each sample using a custom script (Alexander, 2018a) to utilize BWA v0.7.17 (Li, 2013; Li \& Durbin, 2009) for reference mapping, PICARD v2.18.1 (http://broad institute.github.io/picard/) to mark duplicate reads, GATK v3.8.1.0 and 
v4.0.2.1 (DePristo et al., 2011; McKenna et al., 2010; Van der Auwera et al., 2013) for variant calling, and SAMTOOLS v1.7 (Li et al., 2009) to generate pileup output. As GATK assumes that the ends of reads are more error prone, it typically will not call variants found only at read ends. However, this can cause GATK to miss true variants near the end of amplicons, as these will be located at the ends of reads because reads cannot span the end of the amplicon (see https://gatkforums.broadinstitute.org/gatk/ discussion/8477/two-validated-variants-missed-by-haplotypecallerusing-mip-data-amplicon-like-data and associated posts). To circumvent this problem, we generated fasta files for downstream analyses using the majority base call represented in the pileup file using a custom $\mathrm{R}$ script (Alexander, 2018b), utilizing the DATA.TABLE and GGPLOT2 (Wickham, 2016) packages. We carried out the steps described above using the newly generated sample-specific sequence as the reference until no further changes between an alignment of the earlier and latest version of these references were detected for each sample.

We then examined potentially misassembled sequence by evaluating sites where the majority base did not reflect $\geq 70 \%$ of reads (following Morin et al., 2018) and screened for nuclear-encoded mitochondrial pseudogenes by detecting uneven read depth and/or significant missense/nonsense mutations. Finally, we aligned mitochondrial genomes across the samples in GENEIOUs v11.0.5 (Kearse et al., 2012) using default settings, annotated the alignment by comparison with the annotated partial V. germanica mitochondrial genome, masked primer positions and identified the position of any SNPs for regions covered by at least two individuals.

\section{8 | Haplotype fitness effects}

Because of the crucial role mitochondria play in energy metabolism, we expected variation in mitochondrial sequences to associate with changes in worker and queen cell numbers. To test this hypothesis, we examined 51 nests from New Zealand. Haplotypes with low frequencies (rare: A1, A2, B1, B2) were grouped together and compared with the more common haplotypes A, B and C. We used a negative-binomial distributed generalized linear model in $\mathrm{R}$ with haplotype, sampling year and sampling location as predictors to test which predictor best described the variation in worker cell number. For the queen cell numbers, zero inflation was included in the model to account for excess zero counts of nests with no queen cells using the zeroinfl function in the PSCL package (Jackman, 2017; Zeileis, Kleiber, \& Jackman, 2008) and otherwise the same predictors and distribution as the worker cell model. We were unable to examine variation in fitness associated with different haplotypes in Belgium, because a high level of genetic diversity meant that few haplotypes were represented by more than one replicate.

\section{3 | RESULTS}

\subsection{Colony fitness analysis}

Out of 32 nests in Belgium and 62 nests in New Zealand, 29 (91\%) and 46 (74\%), respectively, had queen cells. There was no significant difference in the percentage of queen producing nests between populations $\left(\chi^{2}=2.588, d f=1, p=.108\right)$. The size of a queen cell in New Zealand was $38.8 \pm 5.0 \mathrm{~mm}^{2}$ (mean \pm standard deviation $[S D]$ ), significantly larger than the $33.7 \pm 7.3 \mathrm{~mm}^{2}$ of Belgian queen cells ( $t$ test: $t=3.264, p=.002$ ). Worker cells did not differ in size (New Zealand $=19.1 \pm 2.0 \mathrm{~mm}^{2}$, Belgium $=18.3 \pm 3.0 \mathrm{~mm}^{2}$; $t$ test: $t=1.318, p=.194)$. Nests in the native range of Belgium contained $1,492 \pm 1,286$ (mean $\pm S D$ ) queen and 8,671 \pm 3,671 worker cells, which was significantly more than $586 \pm 598$ queen and $6,707 \pm 3,818$ worker cells in nests from the invasive population in New Zealand ( $t$ test: $t=-3.779, p<.001$ and $t=-2.425, p=.018$, respectively; Figure 3). Nests without any queen cells and small nests, consisting of $<2,000$ cells, were found in all sampling locations (Figure 3 , details on nests can be found in Table S2). In Belgium, where nests were sampled over 3 weeks, Spearman's correlation test showed no significant effect of sampling day on number of queen or worker cells in mature colonies (2016 data only; worker cell: $r=-.159, p=.622$; queen cell: $r=.417, p=.176$ ).

In both populations, the number of queen cells was significantly and positively correlated with the number of worker cells (Belgium: Pearson $r=.465, p=.007$; New Zealand: $r=.468, p<.001$ ). Worker cells are used multiple times and therefore do not directly represent worker number. Yet, the relationship of the two cell types can be used as an indication of how many workers are needed to rear a new queen, suggesting that the native population is twice as efficient in rearing new queens as the invasive population (slope in Equations 1 and 2).

Queen cell number $=$ Intercept $( \pm S E)+$ slope $( \pm S E) \times$ worker number

Belgium: Queen cell number $=78.77( \pm 532.00)+0.16( \pm 0.06)$ $\times$ worker cell number

New Zealand: Queen cell number $=93.73( \pm 137.70)+0.07( \pm 0.02)$

$$
\times \text { worker cell number }
$$

\subsection{Genetic variation and population structure}

Sanger sequencing of 70 wasp nests (Belgium: $n=19$, New Zealand: $n=51$ ) revealed 26 synonymous polymorphisms in $1,872 \mathrm{bp}$ of mtDNA that resulted in 20 unique haplotype sequences (Table 2). We found eight variable sites in CytB, 16 in Cox1, two in Cox2 and none in the tRNA-Leu or the intergenic region. Using the HasegawaKishino-Yano model (Hasegawa, Kishino \& Yano, 1985), Tajima's neutrality test detected no significant selective sweeps or changes in population size (Table S3). Over 53\% of the genetic variance in our total sample could be explained by partitioning our samples into New Zealand versus Belgian samples, suggesting little-to-no ongoing gene flow between the native and introduced range (AMOVA, $\Phi=.532, p<.001$, Table S4).

Of the 20 total haplotypes, seven were present in New Zealand and 14 in Belgium, with only one haplotype (B) found in both populations (Figure 4). Overall, haplotype diversity and nucleotide diversity were lower in the invasive population in comparison with the native population (Table 2). Haplotypes in New Zealand were closely related (Figure 4). Three haplotypes found in all three New Zealand sampling sites (A: $39.2 \%$ of nests, B: $31.4 \%$ and C: $19.6 \%$ ) were classified as common, while the four remaining haplotypes accounted 
for only $9.8 \%$ of nests and were classified as rare (Figure 1). In the Belgian population, most haplotypes had relatively low frequencies, the highest frequency was observed in haplotype M1 with $21.1 \%$ (Figure 1). However, we analysed only 19 nests from Belgium and a larger sample size could have established higher frequencies for some haplotypes. Rarefaction analysis indicated we likely discovered most haplotypes in the Nelson Lakes National Park in New Zealand but only a fraction of haplotypes in Belgium (Figure S1).

\subsection{Whole mitochondrial genome sequencing}

We sequenced whole mitochondrial genomes of 10 samples from New Zealand, representing two samples from different sampling sites for haplotype $A, B, C$, and $A 2$, and one sample each from A1 and B1. We observed "craters" in read depth across all samples assembled in this study, at consistent locations along the mitochondrial genome (Figure S2). To ensure that these areas of low depth did not result from divergence of the reference mitochondrial genome to our sequenced samples at these positions, we also carried out de novo assemblies of our samples (with both TRINITY v2.6.5: [Grabherr et al., 2011] and Geneious), using contigs with $>75 \%$ BLAST match to the reference mitochondrial genome to construct sample-specific references. As the sample-specific references also suffered from the same consistent zones of low depth, it is likely that some kind of
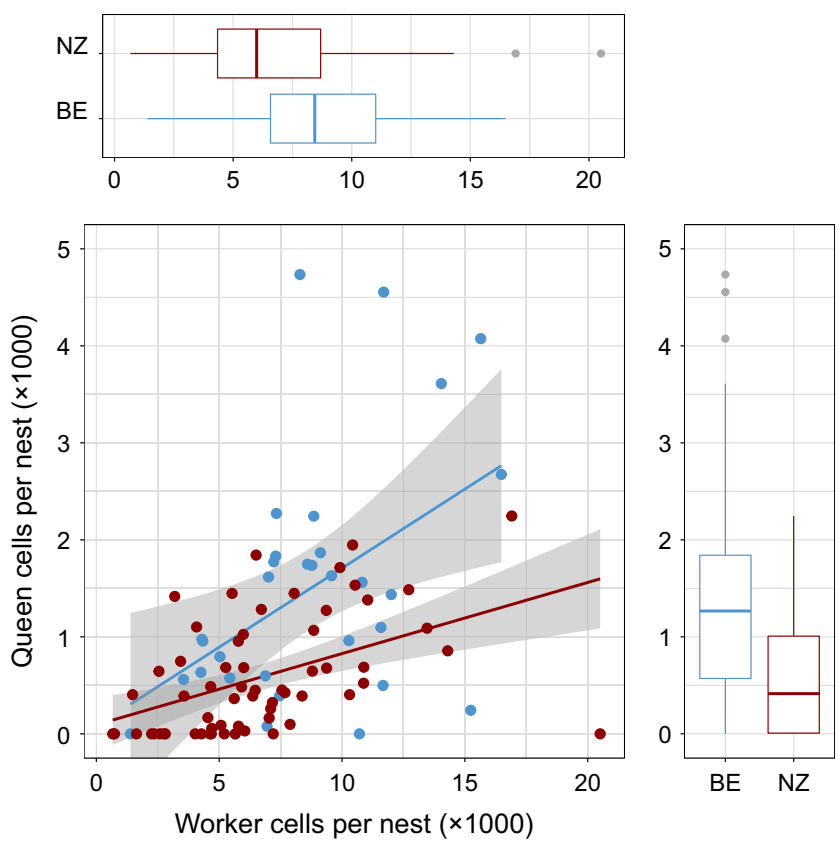

FIGURE 3 Nest size and productivity in Belgium and New Zealand. Worker and queen cells per nest in Belgium (BE, in blue/ light grey, $n=32$ ) and New Zealand (NZ, in red/ dark grey, $n=62$ ). Top: Boxplots of worker cell numbers. Bottom left: The relationship between worker and queen cell numbers per nest. Lines show linear regression with 95\% confidence region in grey. Bottom right: Boxplot of queen cells numbers. Boxplots with median, 25th and 75th percentiles, whiskers extending to $95 \%$ confidence interval, and outliers identified by grey circles [Colour figure can be viewed at wileyonlinelibrary.com] interference exists in the assemblies at those locations, for example reads mapping to co-amplified pseudogenes or nontarget regions rather than to the mitochondrial genome.

To minimize the chance of inadvertently including pseudogenic regions in our assembly, we masked any regions of the mitochondrial genomes where sequencing depth was $\leq 10 \%$ of the maximum depth observed for that sample. Even after this masking step, the majority of the mitochondrial genome was recovered for each individual with an average of 12,743 bp across all samples (the "least covered" mitochondrial genome had 11,910 bp of sequence [Table S2, sample: VV2016 Six Mile 8]). The protein-coding genes were identified by using the partially annotated Vespula germanica genome (KR703583; Figure S3): ND1, CytB, ND4, ND3, Cox3, ATP6, ATP8, Cox2 and Cox1 had full-length alignments for all samples, while ND6, ND4L and ND5 were at least partially covered by all samples. In a comparison of these sequences to the Sanger sequencing data generated in this study, no mismatches were detected, apart from a constant mismatch at site 13 of the Sanger CytB data (where all the Illumina data had a G, and all Sanger sequences had an A). This mismatch is a primer artefact caused by an $A$ at the 24th base in the sequencing primer used for CytB (CB11367 in Table 1).

Across all the positions with Illumina data for at least two samples, we found a total of 16 variants: four in the control region (dloop), seven in protein-coding regions, three in intergenic regions, one in the $12 \mathrm{~S}$ rRNA and one in tRNA-Cys (Figure 5). The variation in the control region was caused by differences in the number of repeats of a 10 bp motif (AAAATGCAAA). Most samples $(n=8)$ had 13 repeats, while one $B$ haplotype sample had 11 and one $A 2$ sample had 15 repeats, including two imperfect repeats where there was an additional A (i.e., two repeats that were $11 \mathrm{bp}$ rather than $10 \mathrm{bp}$ ). Six out of seven SNPs in protein-coding genes were covered by Sanger sequencing used to determine the haplotypes. The additional polymorphism in ND6 only occurred in haplotype C. All polymorphisms were synonymous causing no changes in the amino acid sequence. The intergenic region between ND6 and tRNA-Pro varied in length from 55 bp in one of the $B$ haplotypes (B4) through 56 bp in the other $B$ sample and haplotypes $C$ and $A 1$, to 57 bp in all other haplotypes. An insertion of $\mathrm{T}$ in the $12 \mathrm{~S}$ rRNA was found in both $\mathrm{B}$ samples. The variation in tRNA-Cys was located at the end of the acceptor stem at the $5^{\prime}$ end: five samples had an $11 \mathrm{~A}$ homopolymer instead of the 10 A homopolymer found in the other samples; however, this variation was inconsistent within samples of the same haplotype. The ten partial mitochondrial genome sequences have been uploaded to GenBank (MK737074-MK737083).

\section{4 | Haplotype fitness effects}

For the New Zealand population, we analysed the effect of haplotype on queen and worker cell number. Worker cell numbers slightly differed between haplotypes (mean $\pm S D$ : $A=8,303 \pm 5,502$, $n=20 ; B=5,426 \pm 2,596, n=16 ; C=6,024 \pm 2,537, n=10$; rare $=6,046 \pm 1,561, n=5$; Figure 6). Haplotype A showed the greatest variation in worker cell number and the nest with the 
TABLE 2 Genetic variability in the native and invaded range

\begin{tabular}{llllrll} 
Population & $\boldsymbol{n}$ & Variable sites & Singleton sites & $\boldsymbol{H}$ & HD & $\boldsymbol{\pi}$ \\
\hline NZ & 51 & 7 & 3 & 7 & 0.721 & $7.20 \times 10^{-4}$ \\
BE & 19 & 20 & 11 & 14 & 0.953 & $2.16 \times 10^{-3}$ \\
\hline Total & 70 & 26 & 13 & 20 & 0.843 & $1.60 \times 10^{-3}$ \\
\hline
\end{tabular}

Note: Number of nests ( $n$ ), variable Sanger sequencing sites, singleton Sanger sequencing sites, number of haplotypes $(H)$, haplotype diversity $(H D)$ and nucleotide diversity $(\pi)$ are shown for New Zealand (NZ), Belgium (BE) and in total. most overall worker cells. The negative-binominal generalized linear model revealed a negative effect on worker cell number of haplotype $\mathrm{B}(z=-2.421, p=.016)$, while sampling year and location had no effect (all $p>$.05). Only common haplotypes were found to produce more than 100 queen cells and frequently had around 500 queen cells, whereas nests with rare haplotypes produced few queen cells, if any (Figure 6). Overall, queen cell number in the rare haplotypes (mean $\pm S D: 43 \pm 47, n=5$ ) was lower than in the common haplotypes (mean $\pm S D: A=622 \pm 634, n=20$; $B=399 \pm 440, n=16 ; C=586 \pm 637, n=10$ ). The generalized linear model revealed that this observation was statistically significant $(z=-5.509, p<.001)$. Additionally, the model showed that the sampling site Tin Line had fewer queen cells $(z=-2.097, p=.036)$, while other sites and sampling years did not affect queen numbers (all $p>.05$ ).

\section{4 | DISCUSSION}

We examined whether relative fitness in native and invasive populations of the common wasp is associated with mtDNA variation. The density of wasps and wasp nests in the invasive population in New Zealand is extremely high (Beggs et al., 1998; Lester et al., 2017), but surprisingly, nests in New Zealand were significantly smaller and had fewer queen cells, compared to the native range of Belgium, where wasps occur at much lower densities (Archer, 2001). Some invasive social insects experience fitness losses due to reduced genetic diversity (Darrouzet, Gevar, Guignard, \& Aron, 2015; Tsuchida, Kudo, \& Ishiguro, 2014), while in rare cases, diversity loss has benefited the invader (Tsutsui, Suarez, Holway, \& Case, 2000). We found reduced genetic diversity in the New Zealand invasive population, which is in agreement with other studies (Lester \& Beggs, 2019). This reduced genetic diversity, however, does not inhibit wasps attaining large nests that produce many queen cells (Donovan, 1984; Leathwick, Godfrey, Fordham, \& Potter, 1999).

Within the New Zealand population, we found that rare haplotypes were associated with reduced colony fitness. We expected that the association of haplotypes with reduced colony fitness would be caused by mtDNA polymorphisms that affect energy metabolism. Surprisingly, none of the sequence variation across haplotypes resulted in changes in the amino acid sequence (nonsynonymous) that would obviously impair mitochondrial function. However, haplotype $B$, which was the only haplotype found in both New Zealand and Belgium, was associated with a negative effect on worker but not queen cell number, which indicates that fewer workers are needed to rear a queen. Whole mitochondrial genome sequencing revealed a $\mathrm{T}$
FIGURE 4 Mitochondrial haplotype network. Genetic relationship of haplotypes in New Zealand (top layer) and Belgium (bottom layer). Circle size indicates the frequency of a haplotype, small black circles show an additional mutational step, and blank circles are haplotypes absent in the population. Only haplotype " $B$ " was present in both populations, as indicated by the lines connecting this haplotype in both layers [Colour figure can be viewed at wileyonlinelibrary.com]

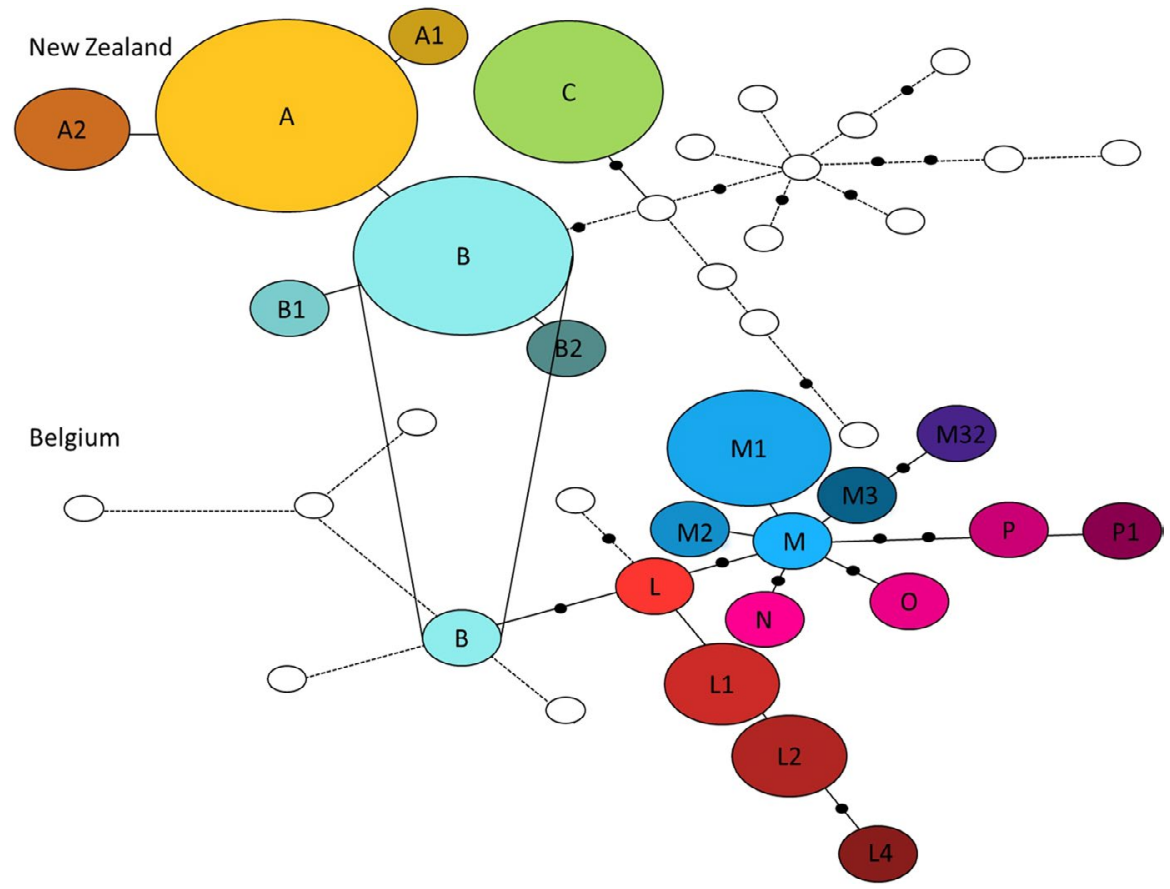




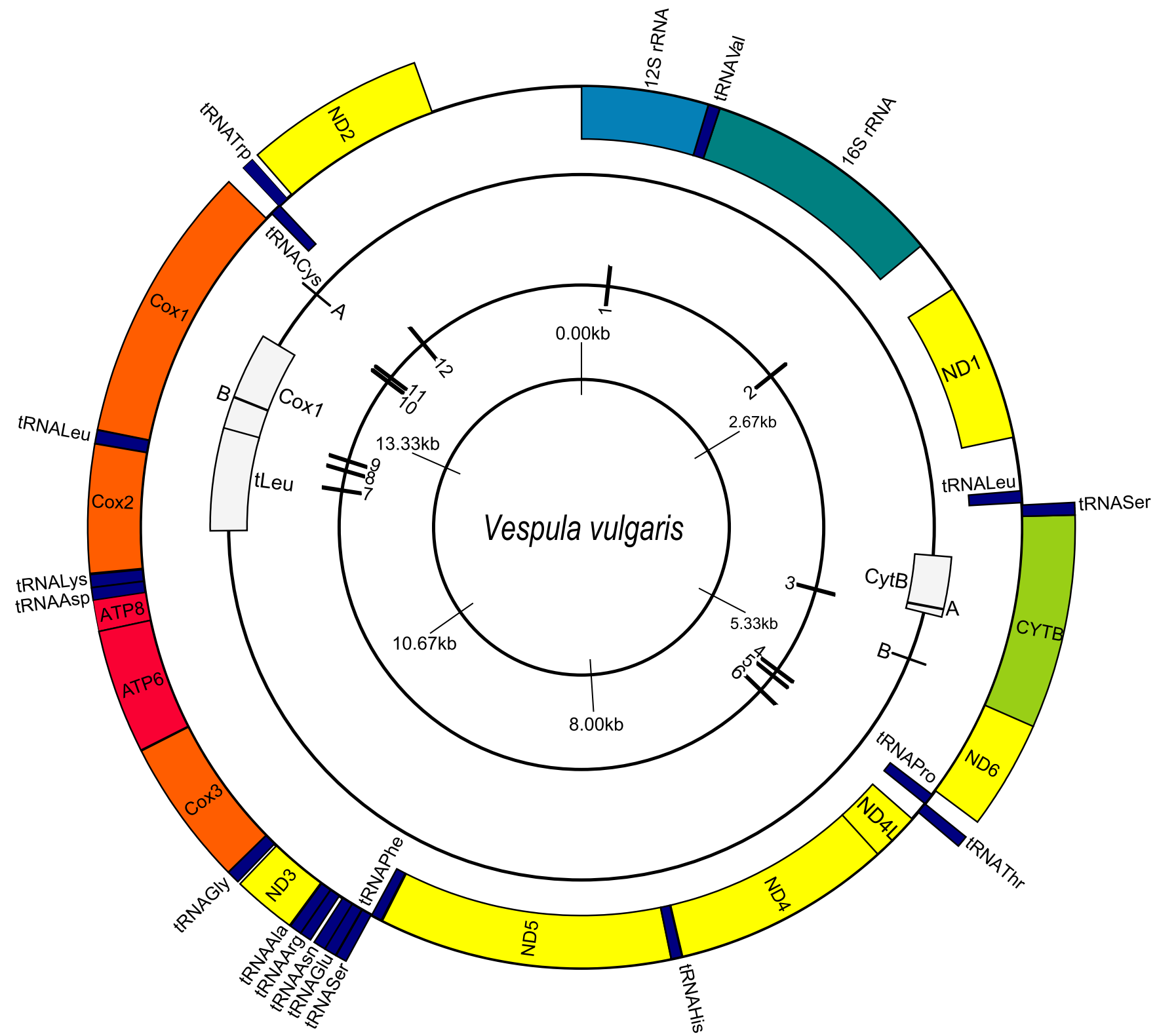

FIGURE 5 Map of circular mitochondrial genome of Vespula vulgaris. Concentric circles from the centre to the periphery: (a) size in kilobase pairs; (b) 12 variable sites in whole mtDNA sequencing; 4 variable sites in the control region (d-loop) not shown; (c) position of PCR and Sanger sequencing primers used to determine haplotypes (grey boxes) and long-range PCR primer for whole mtDNA sequencing (black dashes), forward primer inward facing, reverse primer outward facing; (d) position of coding regions and tRNAs, inward facing on light strand, outward facing on heavy strand. The Vespula germanica mitochondrial genome (GenBank Accession no. KR703583) was used as a reference, map generated using GenomeVx (Conant \& Wolfe, 2008) [Colour figure can be viewed at wileyonlinelibrary.com]

insertion in the $12 \mathrm{~S}$ rRNA of this haplotype that might affect its secondary structure. In New Zealand, haplotype B represented $31.4 \%$ of nests and produced many queens. Therefore, variation in $12 \mathrm{~S}$ rRNA may positively affect relative fitness. However, below we discuss several factors that may have limited our ability to uncover further potential causal variants, including limitations in the use of queen cells as indicators of colony fitness; fitness effects of synonymous mtDNA variants; and infections with the maternally inherited intracellular bacterium Wolbachia. We conclude with a discussion of future research directions into the impact of mtDNA variants on the fitness of introduced populations.

\section{1 | Colony characteristics and queen cells as an indicator of colony fitness}

Wasp colonies are annual and only produce one generation of males and new queens in late summer and autumn, and thus, the number of queen cells is a direct representation of the output of daughter queens for a queen or matriline. This estimate is commonly used to describe fitness in Vespula species (Archer, 1980; Dobelmann et al., 2017; Goodisman, Kovacs, \& Hoffman, 2007) but does not account for the fitness gain from male offspring. Sex ratios in some social wasps can show considerable variation, with some colonies 
FIGURE 6 Effect of haplotype on worker and queen cell numbers in New Zealand. Worker (left) and queen (right) cells per nests in haplotype A $(n=20), B$ ( $n=16), C(n=10)$ and rare haplotypes ( $n=5$, four haplotypes). Boxplots with median, 25th and 75th percentiles, and whiskers extending to $95 \%$ confidence interval. Points show individual data points [Colour figure can be viewed at wileyonlinelibrary.com]

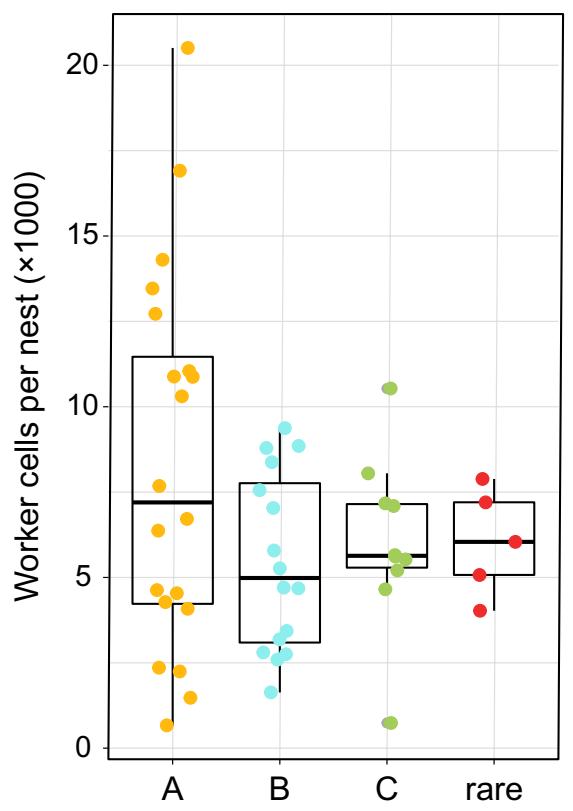

rearing predominantly either queens or males in their reproductive phase (Bonckaert, van Zweden, d'Ettorre, Billen, \& Wenseleers 2011; Greene, 1984). Intracolony genetic diversity in Vespula wasps caused by multiple mating of the queen has been associated with variable sex ratios and queen production (Dobelmann et al., 2017; Goodisman et al., 2007; Johnson et al., 2009), indicating the importance of genetic diversity within a colony. However, observations for Vespula vulgaris suggest equal production of males and queens (Archer, 1980, 1998), but it is not currently known whether these ratios can shift with invasion (Gloag et al., 2019). Rearing queens requires specifically built cells, so nests with few worker wasps may switch from producing costly queens to producing smaller male offspring that can be reared in existing cells. It is therefore possible that reduced queen production, which we used as a fitness indicator, could result from increased investment into male offspring rather than an overall decrease in fitness.

The different metabolic demands of a new environment could also affect resource allocation to queen cells. Common wasps have been established in New Zealand for about 35 years (Donovan, 1984). Traits that promote reproduction and dispersal may be selected for during invasion and range expansion but reduce allocation of resources towards competitive ability (Burton, Phillips, \& Travis, 2010). We found that queen cell size, which directly affects the size of queens reared in these cells, was significantly larger in New Zealand compared with Belgium, while worker cell size did not differ between populations. Larger, high-quality queens are more successful in the colony founding stage, have more fat reserves to survive winter hibernation (Archer, 1981; Harris \& Beggs, 1995) and may represent a trait that is beneficial during range expansion and invasion. Plasticity in offspring size is found in many taxa: mothers can adjust offspring size to maximize fitness (Marshall, Pettersen, \& Cameron, 2018). Competition has been shown to affect quality as well as quantity of workers and new queens produced by social insect colonies (Beggs et al., 2011; Tibbetts \& Curtis, 2007). The extremely high density of wasps is an outstanding characteristic of the honeydew beech forest (Beggs et al., 1998), leading to intense competition for honeydew with native species and among wasp colonies. Whether larger, but fewer, queens in New Zealand indicate a reduction in fitness, a trade-off to a different environment or a trait for range expansion and successful colonization needs to be studied further.

\section{2 | Fitness effects of "synonymous" mtDNA variants}

Interestingly, haplotypes with low frequencies in the New Zealand population had a significantly lower output of new queens than more common haplotypes, although they were similar in the production of worker cells. Rare haplotypes with reduced relative fitness have also been observed in fruit flies and bumble bees (Christie et al., 2004; Christie, Picornell, Moya, Ramon, \& Castro, 2011; Johnson et al., 2011) and purifying selection likely leads to the observed low frequencies of the deleterious haplotypes (Flight et al., 2011; Montooth, Meiklejohn, Abt, \& Rand, 2010). Analysis of $>11,910 \mathrm{bp}$ of rare and common mitochondrial haplotype sequences among the New Zealand population found no nonsynonymous mutations that would indicate an obvious reason for dysfunction causing the low reproductive output of these rare haplotypes. However, "synonymous" variation, which has been largely neglected when studying fitness variation, can affect transcription, transcript processing, mRNA stability and other factors known to affect mitochondrial function (Chamary, Parmley, \& Hurst, 2006; Plotkin \& Kudla, 2011). For example, synonymous variation has been shown to affect gene expression levels and thermal stress tolerance (Camus et al., 2017; Lajbner, Pnini, Camus, Miller, \& Dowling, 2018).

In addition to nonsynonymous point mutations, length variation due to insertion and deletion of tandem repeats has been found in control regions of insects, fish, mammals and plants and seems 
common within populations and even within individuals (heteroplasmy; Nishizawa, Kubo, \& Mikami, 2000; Ravago, Monje, \& JuinioMenez, 2002; Townsend \& Rand, 2004; Wilkinson \& Chapman, 1991). Although most variation in the control region is considered selectively neutral, substitutions may affect nucleotide synthesis (Fumagalli, Taberlet, Favre, \& Hausser, 1996; Zhang \& Hewitt, 1997) and mtDNA copy number (Butler et al., 2016). Through whole mitochondrial genome sequencing, we found variation in the number of tandem repeats in the control region in two samples, although this variation on its own did not seem to be strongly associated with haplotype fitness. However, our overall findings add to evidence that synonymous substitutions or changes in noncoding regions could affect mitochondrial function (Camus et al., 2017; Lajbner et al., 2018).

\section{3 | Wolbachia infections}

Another potential cause for selective disadvantage of rare haplotypes is infections with the maternally inherited intracellular bacterium Wolbachia. Wolbachia infections are common in arthropod hosts and have been found in wasps, including V. vulgaris (Evison et al., 2012; Werren, Zhang, \& Guo, 1995). The spread of incompatibility inducing Wolbachia can drive mitochondrial haplotype frequencies by providing fitness benefits to infected matrilines (Schuler et al., 2016; Turelli \& Hoffmann, 1991). A recent study in the Monomorium pharaonis ant found that Wolbachia-infected colonies had fewer males and femalebiased sex ratios that favoured Wolbachia transmission (Pontieri, Schmidt, Singh, Pedersen, \& Linksvayer, 2017). Though some hosts have lost microbial infections, including Wolbachia, in their invaded ranges (Tsutsui, Kauppinen, Oyafuso, \& Grosberg, 2003; Yang et al., 2010). Reproductive effects of Wolbachia infections have not yet been studied in common wasps but may contribute to skews in haplotype frequencies and observed fitness effects.

\section{5 | CONCLUSIONS}

We found evidence of rare mtDNA variants that were associated with reduced colony fitness, although we failed to identify any obvious causal variant. Simultaneously, examining nuclear and mitochondrial genetic variation could be an important line of future research. Coadapted nuclear-encoded mitochondrial genes can restore deleterious effects caused by mtDNA polymorphisms (Dowling et al., 2008; Meiklejohn, Montooth, \& Rand, 2007) so that a disruption of the two genomes can lead to mtDNA haplotypes becoming deleterious after being introduced into a new range (Amoutzias et al., 2016; Smith et al., 2010). In addition, functional differences of mtDNA are sensitive to variation in climate, which may differ in a new environment (Lamb et al., 2018). This three-way interaction between mtDNA, nuclear genotype and the environment contributes to organismal fitness and could influence mitochondrial genetic diversity within populations (Arnqvist et al., 2010). Understanding maintenance of variation and selective responses relies on identification of mtDNA variants that affect phenotypic traits (Barton \& Keightley, 2002).
In this study, we have gained insights into mitochondrial haplotype associated fitness variation in an introduced species of social wasps. Seeking evidence for links between fitness and mtDNA variation can improve understanding of how natural selection maintains variation and shapes haplotype patterns observed in wild populations. Moreover, linking fitness to mtDNA variation can improve management of populations for conservation but also for control of invasive species or pests (Gemmell, Jalilzadeh, Didham, Soboleva, \& Tompkins, 2013). This is one of the few studies that have obtained evidence for theoretical expectations that mtDNA variation impacts fitness in wild nonmodel populations.

\section{ACKNOWLEDGEMENTS}

This research was supported by a Royal Society Te Apārangi grant (13-VUW-037) and the Ministry of Business, Innovation and Employment (New Zealand's Biological Heritage NSC, C09X1501). We thank four anonymous reviewers and the editor for their valuable comments that helped to improve the manuscript.

\section{AUTHOR CONTRIBUTIONS}

P.J.L. conceived the study. J.D., A.A., J.W.B., N.J.G., M.A.M.G., O.Q. and T.W. contributed samples, data or expert interpretation. J.D., A.A., J.W.B. and O.Q. analysed the data with the support of P.J.L. and N.J.G. J.D. led the writing of the manuscript with contributions from all authors.

\section{DATA AVAILABILITY STATEMENT}

The data that support the findings of this study are openly available in Dryad at http://doi.org/10.5061/dryad.17jnOfq (Dobelmann et al., 2019) (nest analysis), and mtDNA sequences were deposited in NCBI GenBank (http://www.ncbi.nlm.nih.gov/) as Accession nos. MK737074-MK737083 (partial mitochondrial genome sequences) and MK967473-MK967508 (haplotype sequences).

\section{ORCID}

Jana Dobelmann (iD https://orcid.org/0000-0002-6742-0945

Alana Alexander (iD https://orcid.org/0000-0002-6456-7757

James W. Baty (iD https://orcid.org/0000-0002-7961-3234

Neil J. Gemmell iD https://orcid.org/0000-0003-0671-3637

Monica A. M. Gruber (iD https://orcid.org/0000-0001-6780-8838

Oliver Quinn (D) https://orcid.org/0000-0002-9135-3447

Tom Wenseleers iD https://orcid.org/0000-0002-1434-861X

Philip J. Lester (iD https://orcid.org/0000-0002-1801-5687

\section{REFERENCES}

Alexander, A. (2018a). 3_reference_mapping. Retrieved from https:// github.com/laninsky/direct_mito_sequencing/tree/master/3_refer ence_mapping 
Alexander, A. (2018b). 4_filtering_fasta_on_pileup. Retrieved from https://github.com/laninsky/direct_mito_sequencing/tree/maste r/4_filtering_fasta_on_pileup

Amoutzias, G. D., Giannoulis, T., Moutou, K. A., Psarra, A. M., Stamatis, C., Tsipourlianos, A., \& Mamuris, Z. (2016). SNP identification through transcriptome analysis of the European brown hare (Lepus europaeus): Cellular energetics and Mother's curse. PLoS ONE, 11(7), e0159939. https://doi.org/10.1371/journal.pone.0159939

Arca, M., Mougel, F., Guillemaud, T., Dupas, S., Rome, Q., Perrard, A., ... Silvain, J.-F. (2015). Reconstructing the invasion and the demographic history of the yellow-legged hornet, Vespa velutina in Europe. Biological Invasions, 17(8), 2357-2371. https://doi.org/10.1007/ s10530-015-0880-9

Archer, M. E. (1980). Population dynamics. In R. Edwards (Ed.), Social wasps: Their biology and control (pp. 172-207). East Grinstead, UK: Rentokil Limited.

Archer, M. E. (1981). Successful and unsuccessful development of colonies of Vespula vulgaris (Linn.) (Hymenoptera: Vespidae). Ecological Entomology, 6(1), 1-10. https://doi.org/10.1111/j.1365-2311.1981.tb00966.x

Archer, M. E. (1998). Worker versus sexual, and sex ratio investments in the social wasp Vespula vulgaris (L.) (Hymenoptera: Vespinae) in England. Journal of Hymenoptera Research, 7, 257-267.

Archer, M. (2001). Changes in abundance of Vespula germanica and V. vulgaris in England. Ecological Entomology, 26(1), 1-7. https://doi. org/10.1046/j.1365-2311.2001.00296.x

Arnqvist, G., Dowling, D. K., Eady, P., Gay, L., Tregenza, T., Tuda, M., \& Hosken, D. J. (2010). Genetic architecture of metabolic rate: Environment specific epistasis between mitochondrial and nuclear genes in an insect. Evolution, 64(12), 3354-3363. https://doi. org/10.1111/j.1558-5646.2010.01135.x

Auguie, B. (2016). gridExtra: Miscellaneous functions for "grid" graphics. $R$ package version 2.2.1. Retrieved from https://cran.r-project.org/ package $=$ gridExtra

Ballard, J. W. O., Pichaud, N., \& Fox, C. (2014). Mitochondrial DNA: More than an evolutionary bystander. Functional Ecology, 28(1), 218-231. https://doi.org/10.1111/1365-2435.12177

Barton, N. H., \& Keightley, P. D. (2002). Understanding quantitative genetic variation. Nature Reviews Genetics, 3(1), 11-21. https://doi. org/10.1038/nrg700

Beggs, J. R., Brockerhoff, E. G., Corley, J. C., Kenis, M., Masciocchi, M., Muller, F., ... Villemant, C. (2011). Ecological effects and management of invasive alien Vespidae. BioControl, 56(4), 505-526. https://doi. org/10.1007/s10526-011-9389-z

Beggs, J. R., Toft, R. J., Malham, J. P., Rees, J. S., Tilley, J. A. V., Moller, H., \& Alspach, P. (1998). The difficulty of reducing introduced wasp (Vespula vulgaris) populations for conservation gains. New Zealand Journal of Ecology, 22(1), 55-63.

Blier, P. U., Dufresne, F., \& Burton, R. S. (2001). Natural selection and the evolution of mtDNA-encoded peptides: Evidence for intergenomic co-adaptation. Trends in Genetics, 17(7), 400-406. https://doi. org/10.1016/S0168-9525(01)02338-1

Bock, D. G., Caseys, C., Cousens, R. D., Hahn, M. A., Heredia, S. M., Hübner, S., ... Rieseberg, L. H. (2015). What we still don't know about invasion genetics. Molecular Ecology, 24(9), 2277-2297. https://doi. org/10.1111/mec.13032

Bonckaert, W., van Zweden, J. S., d'Ettorre, P., Billen, J., \& Wenseleers, T. (2011). Colony stage and not facultative policing explains pattern of worker reproduction in the Saxon wasp. Molecular Ecology, 20(16), 3455-3468. https://doi.org//10.1111/j.1365-294X.2011.05200.x

Burton, O. J., Phillips, B. L., \& Travis, J. M. (2010). Trade-offs and the evolution of life-histories during range expansion. Ecology Letters, 13(10), 1210-1220. https://doi.org/10.1111/j.1461-0248.2010.01505.x

Camus, M. F., Clancy, D. J., \& Dowling, D. K. (2012). Mitochondria, maternal inheritance, and male aging. Current Biology, 22(18), 1717-1721. https://doi.org/10.1016/j.cub.2012.07.018
Camus, M. F., Wolf, J. B., Morrow, E. H., \& Dowling, D. K. (2015). Single nucleotides in the mtDNA sequence modify mitochondrial molecular function and are associated with sex-specific effects on fertility and aging. Current Biology, 25(20), 2717-2722. https://doi.org/10.1016/j. cub.2015.09.012

Camus, M. F., Wolff, J. N., Sgro, C. M., \& Dowling, D. K. (2017). Experimental support that natural selection has shaped the latitudinal distribution of mitochondrial haplotypes in Australian Drosophila melanogaster. Molecular Biology and Evolution, 34(10), 2600-2612. https://doi.org/10.1093/molbev/msx184

Carcamo, J. R., Contador, T., Crego, R. D., Jordan, N. I., Schuttler, E., Ganan, M., ... Kennedy, J. H. (2016). First record of Vespula vulgaris (Linnaeus 1758) (Hymenoptera: Vespidae); on Navarino Island, Chile. Gayana, 80(1), 133-136.

Chamary, J. V., Parmley, J. L., \& Hurst, L. D. (2006). Hearing silence: Nonneutral evolution at synonymous sites in mammals. Nature Reviews Genetics, 7(2), 98-108. https://doi.org/10.1038/nrg1770

Chapman, R. E., \& Bourke, A. F. G. (2001). The influence of sociality on the conservation biology of social insects. Ecology Letters, 4(6), 650-662. https://doi.org/10.1046/j.1461-0248.2001.00253.x

Christie, J. S., Castro, J. A., Oliver, P., Picornell, A., Ramon, M. M., \& Moya, A. (2004). Fitness and life-history traits of the two major mitochondrial DNA haplotypes of Drosophila subobscura. Heredity, 93(4), 371378. https://doi.org/10.1038/sj.hdy.6800513

Christie, J. S., Picornell, A., Moya, A., Ramon, M. M., \& Castro, J. A. (2011). Mitochondrial DNA effects on fitness in Drosophila subobscura. Heredity, 107(3), 239-245. https://doi.org/10.1038/hdy.2011.8

Clancy, D. J. (2008). Variation in mitochondrial genotype has substantial lifespan effects which may be modulated by nuclear background. Aging Cell, 7(6), 795-804. https://doi. org/10.1111/j.1474-9726.2008.00428.x

Conant, G. C., \& Wolfe, K. H. (2008). GenomeVx: Simple web-based creation of editable circular chromosome maps. Bioinformatics, 24(6), 861-862. https://doi.org/10.1093/bioinformatics/btm598

Darrouzet, E., Gevar, J., Guignard, Q., \& Aron, S. (2015). Production of early diploid males by European colonies of the invasive hornet Vespa velutina nigrithorax. PLoS ONE, 10(9), e0136680. https://doi. org/10.1371/journal.pone.0136680

DePristo, M. A., Banks, E., Poplin, R., Garimella, K. V., Maguire, J. R., Hartl, C., ... Daly, M. J. (2011). A framework for variation discovery and genotyping using next-generation DNA sequencing data. Nature Genetics, 43(5), 491-498. https://doi.org/10.1038/ng.806

Dobelmann, J., Alexander, A., Baty, J. W., Gemmell, N. J., Gruber, M. A. M., Quinn, O., ... Lester, P. J. (2019). Data from: The association between mitochondrial genetic variation and reduced colony fitness in an invasive wasp. Dryad; https://doi.org/10.5061/dryad.17jnOfq

Dobelmann, J., Loope, K. J., Wilson-Rankin, E., Quinn, O., Baty, J. W., Gruber, M. A. M., \& Lester, P. J. (2017). Fitness in invasive social wasps: The role of variation in viral load, immune response and paternity in predicting nest size and reproductive output. Oikos, 126(8), 1208-1218. https://doi.org/10.1111/oik.04117

Donovan, B. J. (1984). Occurrence of the common wasp, Vespula vulgaris (L) (Hymenoptera, Vespidae) in New Zealand. New Zealand Journal of Zoology, 11(4), 417-427. https://doi.org/10.1080/03014 223.1984.10428256

Dowling, D. K., Friberg, U., \& Lindell, J. (2008). Evolutionary implications of non-neutral mitochondrial genetic variation. Trends in Ecology and Evolution, 23(10), 546-554. https://doi.org/10.1016/j.tree.2008.05.011

Elliott, G. P., Wilson, P. R., Taylor, R. H., \& Beggs, J. R. (2010). Declines in common, widespread native birds in a mature temperate forest. Biological Conservation, 143(9), 2119-2126. https://doi.org/10.1016/j. biocon.2010.05.022

Ellison, C. K., \& Burton, R. S. (2006). Disruption of mitochondrial function in interpopulation hybrids of Tigriopus californicus. Evolution, 60(7), 1382-1391. https://doi.org/10.1111/j.0014-3820.2006.tb01217.x 
Evison, S. E. F., Roberts, K. E., Laurenson, L., Pietravalle, S., Hui, J., Biesmeijer, J. C., ... Hughes, W. O. H. (2012). Pervasiveness of parasites in pollinators. PLoS ONE, 7(1), e30641. https://doi.org/10.1371/ journal.pone.0030641

Flight, P. A., Nacci, D., Champlin, D., Whitehead, A., \& Rand, D. M. (2011). The effects of mitochondrial genotype on hypoxic survival and gene expression in a hybrid population of the killifish, Fundulus heteroclitus. Molecular Ecology, 20(21), 4503-4520. https://doi. org/10.1111/j.1365-294X.2011.05290.x

Foster, K. R., \& Ratnieks, F. L. (2001). Convergent evolution of worker policing by egg eating in the honeybee and common wasp. Proceedings of the Royal Society B: Biological Sciences, 268(1463), 169-174. https://doi.org/10.1098/rspb.2000.1346

Fumagalli, L., Taberlet, P., Favre, L., \& Hausser, J. (1996). Origin and evolution of homologous repeated sequences in the mitochondrial DNA control region of shrews. Molecular Biology and Evolution, 13(1), 31-46. https://doi.org/10.1093/oxfordjournals.molbev.a025568

Gemmell, N. J., Jalilzadeh, A., Didham, R. K., Soboleva, T., \& Tompkins, D. M. (2013). The Trojan female technique: A novel, effective and humane approach for pest population control. Proceedings of the Royal Society B: Biological Sciences, 280(1773), 20132549. https://doi. org/10.1098/rspb.2013.2549

Gemmell, N. J., Metcalf, V. J., \& Allendorf, F. W. (2004). Mother's curse: The effect of mtDNA on individual fitness and population viability. Trends in Ecology and Evolution, 19(5), 238-244. https://doi. org/10.1016/j.tree.2004.02.002

Gershoni, M., Templeton, A. R., \& Mishmar, D. (2009). Mitochondrial bioenergetics as a major motive force of speciation. BioEssays, 31(6), 642-650. https://doi.org/10.1002/bies.200800139

Gloag, R. S., Christie, J. R., Ding, G., Stephens, R. E., Buchmann, G., \& Oldroyd, B. P. (2019). Workers' sons rescue genetic diversity at the sex locus in an invasive honey bee population. Molecular Ecology, 28(7), 1585-1592. https://doi.org/10.1111/mec.15031

Goodisman, M.A., Kovacs, J. L., \& Hoffman, E. A. (2007). The significance of multiple mating in the social wasp Vespula maculifrons. Evolution, 61(9), 2260-2267. https://doi.org/10.1111/j.1558-5646.2007.00175.x

Grabherr, M. G., Haas, B. J., Yassour, M., Levin, J. Z., Thompson, D. A., Amit, I., ... Regev, A. (2011). Full-length transcriptome assembly from RNA-Seq data without a reference genome. Nature Biotechnology, 29(7), 644-652. https://doi.org/10.1038/nbt.1883

Greene, A. (1984). Production schedules of vespine wasps: An empirical test of the bang-bang optimization model. Journal of the Kansas Entomological Society, 57(4), 545-568.

Harris, R. J., \& Beggs, J. R. (1995). Variation in the quality of Vespula vulgaris (L.) queens (Hymenoptera: Vespidae) and its significance in wasp population dynamics. New Zealand Journal of Zoology, 22(2), 131-142. https://doi.org/10.1080/03014223.1995.9518030

Hasegawa, M., Kishino, H., \& Yano, T. (1985). Dating of the human-ape splitting by a molecular clock of mitochondrial DNA. Journal of Molecular Evolution, 22(2), 160-174.

Hill, G. E. (2019). Reconciling the mitonuclear compatibility species concept with rampant mitochondrial introgression. Integrative and Comparative Biology. Advance online publication. https://doi. org/10.1093/icb/icz019.

Jackman, J. (2017). pscl: Classes and methods for R developed in the political science computational laboratory. $R$ package version 1.5.2. Retrieved from https://github.com/atahk/pscl/

Jacobs, J. (2011). Individual based rarefaction using R-package. Retrieved from http://jennajacobs.org/R/rarefaction.html

Johnson, A. P., Schmid-Hempel, R., \& Schmid-Hempel, P. (2011). Female lines in social insects - A homage to the Croziers' mitochondria. Myrmecological News, 15, 101-108.

Johnson, E. L., Cunningham, T. W., Marriner, S. M., Kovacs, J. L., Hunt, B. G., Bhakta, D. B., \& Goodisman, M. A. (2009). Resource allocation in a social wasp: Effects of breeding system and life cycle on reproductive decisions. Molecular Ecology, 18(13), 2908-2920. https://doi.org/10.1111/j.1365-294X.2009.04240.x

Kearse, M., Moir, R., Wilson, A., Stones-Havas, S., Cheung, M., Sturrock, S., ... Drummond, A. (2012). Geneious basic: An integrated and extendable desktop software platform for the organization and analysis of sequence data. Bioinformatics, 28(12), 1647-1649. https://doi. org/10.1093/bioinformatics/bts199

Kumar, S., Stecher, G., \& Tamura, K. (2016). MEGA7: Molecular evolutionary genetics analysis version 7.0 for bigger datasets. Molecular Biology and Evolution, 33(7), 1870-1874. https://doi.org/10.1093/ molbev/msw054

Lajbner, Z., Pnini, R., Camus, M. F., Miller, J., \& Dowling, D. K. (2018). Experimental evidence that thermal selection shapes mitochondrial genome evolution. Scientific Reports, 8(1), 9500. https://doi. org/10.1038/s41598-018-27805-3

Lamb, A. M., Gan, H. M., Greening, C., Joseph, L., Lee, Y. P., MoránOrdóñez, A., ... Pavlova, A. (2018). Climate-driven mitochondrial selection: A test in Australian songbirds. Molecular Ecology, 27(4), 898-918. https://doi.org/10.1111/mec.14488

Leathwick, D., Godfrey, P., Fordham, R., \& Potter, M. (1999). Comparative growthand seasonality of Vespulagermanica(F.) and Vespula vulgaris (L.) (Hymenoptera: Vespidae) colonies in the Manawatu region of $\mathrm{New}$ Zealand. New Zealand Journal of Zoology, 26(1), 27-38.

Lester, P. J., \& Beggs, J. R. (2019). Invasion success and management strategies for social Vespula wasps. Annual Review in Entomology, 64(1), 51-71. https://doi.org/10.1146/annurev-ento-011118-111812

Lester, P. J., Gruber, M. A. M., Brenton-Rule, E. C., Archer, M., Corley, J. C., Dvořák, L., ... Roura-Pascual, N. (2014). Determining the origin of invasions and demonstrating a lack of enemy release from microsporidian pathogens in common wasps (Vespula vulgaris). Diversity and Distributions, 20(8), 964-974. https://doi.org/10.1111/ddi.12223

Lester, P. J., Haywood, J., Archer, M. E., \& Shortall, C. R. (2017). The longterm population dynamics of common wasps in their native and invaded range. Journal of Animal Ecology, 86(2), 337-347. https://doi. org/10.1111/1365-2656.12622

$\mathrm{Li}, \mathrm{H} .(2013)$. Aligning sequence reads, clone sequences and assembly contigs with BWA-MEM. arXiv preprint, arXiv:1303.3997, available from: arxiv.org

Li, H., \& Durbin, R. (2009). Fast and accurate short read alignment with Burrows-Wheeler transform. Bioinformatics, 25(14), 1754-1760. https://doi.org/10.1093/bioinformatics/btp324

Li, H., Handsaker, B., Wysoker, A., Fennell, T., Ruan, J., \& Homer, N. ... 1000 Genome Project Data Processing Subgroup (2009). The sequence alignment/map format and SAMtools. Bioinformatics, 25(16), 2078-2079. https://doi.org/10.1093/bioinformatics/btp352

Librado, P., \& Rozas, J. (2009). DnaSP v5: A software for comprehensive analysis of DNA polymorphism data. Bioinformatics, 25(11), 1451-1452. https://doi.org/10.1093/bioinformatics/btp187

Lowe, S., Browne, M., Boudjelas, S., \& De Poorter, M. (2000). 100 of the world's worst invasive alien species: A selection from the global invasive species database (Vol. 12). Auckland, New Zealand: Invasive Species Specialist Group.

MacIntyre, J., \& Hellstrom, P.( 2015). An evaluation of the costs of pest wasps (Vespula species) in New Zealand. Wellington, New Zealand: Department of Conservation and Ministry for Primary Industries.

Marsden, C. D., Ortega-Del Vecchyo, D., O'Brien, D. P., Taylor, J. F., Ramirez, O., Vilà, C., ... Lohmueller, K. E. (2016). Bottlenecks and selective sweeps during domestication have increased deleterious genetic variation in dogs. Proceedings of the National Academy of Sciences of the United States of America, 113(1), 152-157. https://doi. org/10.1073/pnas.1512501113

Marshall, D. J., Pettersen, A. K., \& Cameron, H. (2018). A global synthesis of offspring size variation, its eco-evolutionary causes and consequences. Functional Ecology, 32(6), 1436-1446. https://doi. org/10.1111/1365-2435.13099 
Masciocchi, M., \& Corley, J. (2013). Distribution, dispersal and spread of the invasive social wasp (Vespula germanica) in Argentina. Austral Ecology, 38(2), 162-168. https://doi.org/10.1111/j.1442-9993.2012.02388.x

Matsuura, M., \& Yamane, S. (1990). Biology of the vespine wasps. Berlin, Germany: Springer Verlag.

Matthews, R. W., Goodisman, M. A. D., Austin, A. D., \& Bashford, R. (2000). The introduced English wasp Vespula vulgaris (L.) (Hymenoptera : Vespidae) newly recorded invading native forests in Tasmania. Australian Journal of Entomology, 39, 177-179. https://doi. org/10.1046/j.1440-6055.2000.00173.x

McKenna, A., Hanna, M., Banks, E., Sivachenko, A., Cibulskis, K., Kernytsky, A., ... DePristo, M. A. (2010). The Genome Analysis Toolkit: A MapReduce framework for analyzing next-generation DNA sequencing data. Genome Research, 20(9), 1297-1303. https:// doi.org/10.1101/gr.107524.110

Meiklejohn, C. D., Montooth, K. L., \& Rand, D. M. (2007). Positive and negative selection on the mitochondrial genome. Trends in Genetics, 23(6), 259-263. https://doi.org/10.1016/j.tig.2007.03.008

Minka, T., \& Deckmyn, A. (2016). maps: Draw geographical maps. $R$ package version 3.1.1. Retrieved from https://CRAN.R-project.org/packa ge=maps

Moller, H. (1996). Lessons for invasion theory from social insects. Biological Conservation, 78(1-2), 125-142. https://doi. org/10.1016/0006-3207(96)00022-5

Montooth, K. L., Meiklejohn, C. D., Abt, D. N., \& Rand, D. M. (2010). Mitochondrial-nuclear epistasis affects fitness within species but does not contribute to fixed incompatibilities between species of Drosophila. Evolution, 64(12), 3364-3379. https://doi.org/10.1111/ j.1558-5646.2010.01077.x

Morales, H. E., Sunnucks, P., Joseph, L., \& Pavlova, A. (2017). Perpendicular axes of differentiation generated by mitochondrial introgression. Molecular Ecology, 26(12), 3241-3255. https://doi. org/10.1111/mec.14114

Morin, P. A., Foote, A. D., Baker, C. S., Hancock-Hanser, B. L., Kaschner, K., Mate, B. R., ... Alexander, A. (2018). Demography or selection on linked cultural traits or genes? Investigating the driver of low mtDNA diversity in the sperm whale using complementary mitochondrial and nuclear genome analyses. Molecular Ecology, 27(11), 2604-2619. https://doi.org/10.1111/mec.14698

Nei, M., Maruyama, T., \& Chakraborty, R. (1975). The bottleneck effect and genetic variability in populations. Evolution, 29(1), 1-10. https:// doi.org/10.1111/j.1558-5646.1975.tb00807.x

Nishizawa, S., Kubo, T., \& Mikami, T. (2000). Variable number of tandem repeat loci in the mitochondrial genomes of beets. Current Genetics, 37(1), 34-38. https://doi.org/10.1007/s002940050005

Oksanen, J., Blanchet, F. G., Friendly, M., Kindt, R., Legendre, P., McGlinn, D., ... Wagner, H. (2017). Vegan: Community ecology package. R package version 2.4-2. Retrieved from https://CRAN.R-project.org/package=vegan

Pamilo, P., Gertsch, P., Thorén, P., \& Seppä, P. (1997). Molecular population genetics of social insects. Annual Review of Ecology and Systematics, 28(1), 1-25. https://doi.org/10.1146/annurev.ecolsys.28.1.1

Patel, M. R., Miriyala, G. K., Littleton, A. J., Yang, H., Trinh, K., Young, J. M., ... Malik, H. S. (2016). A mitochondrial DNA hypomorph of cytochrome oxidase specifically impairs male fertility in Drosophila melanogaster. Elife, 5, e16923. https://doi.org/10.7554/eLife.16923

Peakall, R., \& Smouse, P. E. (2012). GenAIEx 6.5: Genetic analysis in Excel. Population genetic software for teaching and research-An update. Bioinformatics, 28(19), 2537-2539. https://doi.org/10.1093/ bioinformatics/bts 460

Peischl, S., Dupanloup, I., Kirkpatrick, M., \& Excoffier, L. (2013). On the accumulation of deleterious mutations during range expansions. Molecular Ecology, 22(24), 5972-5982. https://doi.org/10.1111/ mec.12524

Plotkin, J. B., \& Kudla, G. (2011). Synonymous but not the same: The causes and consequences of codon bias. Nature Reviews Genetics, 12(1), 32-42. https://doi.org/10.1038/nrg2899
Pontieri, L., Schmidt, A. M., Singh, R., Pedersen, J. S., \& Linksvayer, T. A. (2017). Artificial selection on ant female caste ratio uncovers a link between female-biased sex ratios and infection by Wolbachia endosymbionts. Journal of Evolutionary Biology, 30(2), 225-234. https:// doi.org/10.1111/jeb.13012

Prost, S., \& Anderson, C. N. K. (2011). TempNet: A method to display statistical parsimony networks for heterochronous DNA sequence data. Methods in Ecology and Evolution, 2(6), 663-667. https://doi. org/10.1111/j.2041-210X.2011.00129.x

R Core Team (2014). R: A language and environment for statistical computing. Vienna, Austria: R Foundation for Statistical Computing. Retrieved from https://www.R-project.org

Garnas, J. R., Auger-Rozenberg, M.-A., Roques, A., Bertelsmeier, C., Wingfield, M. J., Saccaggi, D. L., ... Slippers, B. (2016). Complex patterns of global spread in invasive insects: Eco-evolutionary and management consequences. Biological Invasions, 18(4), 935-952. https:// doi.org/10.1007/s10530-016-1082-9

Rand, D. M., \& Kann, L. M. (1996). Excess amino acid polymorphism in mitochondrial DNA: Contrasts among genes from Drosophila, mice, and humans. Molecular Biology and Evolution, 13(6), 735-748. https:// doi.org/10.1093/oxfordjournals.molbev.a025634

Ravago, R. G., Monje, V. D., \& Juinio-Menez, M. A. (2002). Length and sequence variability in mitochondrial control region of the milkfish, Chanos chanos. Marine Biotechnology, 4(1), 40-50. https://doi. org/10.1007/s10126-001-0076-4

Rollins, L. A., Woolnough, A. P., Fanson, B. G., Cummins, M. L., Crowley, T. M., Wilton, A. N., ... Sherwin, W. B. (2016). Selection on mitochondrial variants occurs between and within individuals in an expanding invasion. Molecular Biology and Evolution, 33(4), 995-1007. https:// doi.org/10.1093/molbev/msv343

Schindelin, J., Rueden, C. T., Hiner, M. C., \& Eliceiri, K. W. (2015). The Image J ecosystem: An open platform for biomedical image analysis. Molecular Reproduction and Development, 82(7-8), 518-529. https:// doi.org/10.1002/mrd.22489

Schuler, H., Koppler, K., Daxbock-Horvath, S., Rasool, B., Krumbock, S., Schwarz, D., ... Riegler, M. (2016). The hitchhiker's guide to Europe: The infection dynamics of an ongoing Wolbachia invasion and mitochondrial selective sweep in Rhagoletis cerasi. Molecular Ecology, 25(7), 1595-1609. https://doi.org/10.1111/mec.13571

Schwartz, T. S., Arendsee, Z. W., \& Bronikowski, A. M. (2015). Mitochondrial divergence between slow- and fast-aging garter snakes. Experimental Gerontology, 71, 135-146. https://doi. org/10.1016/j.exger.2015.09.004

Simon, C., Frati, F., Beckenbach, A., Crespi, B., Liu, H., \& Flook, P. (1994). Evolution, weighting, and phylogenetic utility of mitochondrial gene sequences and a compilation of conserved polymerase chain reaction primers. Annals of the Entomological Society of America, 87(6), 651-701. https://doi.org/10.1093/aesa/87.6.651

Smith, S., Turbill, C., \& Suchentrunk, F. (2010). Introducing mother's curse: Low male fertility associated with an imported mtDNA haplotype in a captive colony of brown hares. Molecular Ecology, 19(1), 36-43. https://doi.org/10.1111/j.1365-294X.2009.04444.x

Spradbery, J. P. (1971). Seasonal changes in the population structure of wasp colonies (Hymenoptera Vespidae). Journal of Animal Ecology, 40(2), 501-523. https://doi.org/10.2307/3259

Tajima, F. (1989). The effect of change in population size on DNA polymorphism. Genetics, 123(3), 597-601.

Tibbetts, E. A., \& Curtis, T. R. (2007). Rearing conditions influence quality signals but not individual identity signals in Polistes wasps. Behavioral Ecology, 18(3), 602-607. https://doi.org/10.1093/beheco/arm013

Thompson, J., Higgins, D., \& Gibson, T. (1994). CLUSTALW: Improving the sensitivity of progressive multiple sequence through weighing, position-specific gap penalties and weight matrix choice. Nucleic Acids Research, 22, 4673-4680.

Toft, R. J., \& Rees, J. S. (1998). Reducing predation of orb-web spiders by controlling common wasps (Vespula vulgaris) in a New Zealand 
beech forest. Ecological Entomology, 23(1), 90-95. https://doi. org/10.1046/j.1365-2311.1998.00100.x

Townsend, J. P., \& Rand, D. M. (2004). Mitochondrial genome size variation in New World and Old World populations of Drosophila melanogaster. Heredity, 93(1), 98-103. https://doi.org/10.1038/ sj.hdy. 6800484

Tsuchida, K., Kudo, K., \& Ishiguro, N. (2014). Genetic structure of an introduced paper wasp, Polistes chinensis antennalis (Hymenoptera, Vespidae) in New Zealand. Molecular Ecology, 23(16), 4018-4034. https://doi.org/10.1111/mec.12852

Tsutsui, N. D., Kauppinen, S. N., Oyafuso, A. F., \& Grosberg, R. K. (2003). The distribution and evolutionary history of Wolbachia infection in native and introduced populations of the invasive argentine ant (Linepithema humile). Molecular Ecology, 12(11), 3057-3068. https:// doi.org/10.1046/j.1365-294X.2003.01979.x

Tsutsui, N. D., Suarez, A. V., Holway, D. A., \& Case, T. J. (2000). Reduced genetic variation and the success of an invasive species. Proceedings of the National Academy of Sciences of the United States of America, 97(11), 5948-5953. https://doi.org/10.1073/ pnas. 100110397

Turelli, M., \& Hoffmann, A. A. (1991). Rapid spread of an inherited incompatibility factor in California Drosophila. Nature, 353(6343), 440-442. https://doi.org/10.1038/353440a0

Van der Auwera, G. A., Carneiro, M. O., Hartl, C., Poplin, R., Del Angel, G., Levy-Moonshine, A., ... DePristo, M. A. (2013). From FastQ data to high confidence variant calls: The Genome Analysis Toolkit best practices pipeline. Current Protocols in Bioinformatics, 43, 11.10.111.10.33. https://doi.org/10.1002/0471250953.bi1110s43

Werren, J. H., Zhang, W., \& Guo, L. R. (1995). Evolution and phylogeny of Wolbachia: Reproductive parasites of arthropods. Proceedings of the Royal Society B: Biological Sciences, 261(1360), 55-63. https://doi. org/10.1098/rspb.1995.0117

Wickham, H. (2016). ggplot2: Elegant graphics for data analysis. New York, NY: Springer-Verlag.

Wilkinson, G. S., \& Chapman, A. M. (1991). Length and sequence variation in evening bat D-loop mtDNA. Genetics, 128(3), 607-617.
Wolff, J. N., Gemmell, N. J., Tompkins, D. M., \& Dowling, D. K. (2017). Introduction of a male-harming mitochondrial haplotype via 'Trojan Females' achieves population suppression in fruit flies. Elife, 6, e23551. https://doi.org/10.7554/eLife.23551

$\mathrm{Xu}, \mathrm{H}$. (2008). Manipulating the metazoan mitochondrial genome with targeted restriction enzymes. Science, 322(5907), 1466-1466.

Yang, C.-C., Yu, Y.-C., Valles, S. M., Oi, D. H., Chen, Y.-C., Shoemaker, D. W., ... Shih, C.-J. (2010). Loss of microbial (pathogen) infections associated with recent invasions of the red imported fire ant Solenopsis invicta. Biological Invasions, 12(9), 3307-3318. https://doi.org/10.1007/ s10530-010-9724-9

Yee, W. K., Sutton, K. L., \& Dowling, D. K. (2013). In vivo male fertility is affected by naturally occurring mitochondrial haplotypes. Current Biology, 23(2), R55-R56. https://doi.org/10.1016/j.cub.2012.12.002

Zeileis, A., Kleiber, C., \& Jackman, S. (2008). Regression models for count data in R. Journal of Statistical Software, 27(8), 1-25.

Zhang, D. X., \& Hewitt, G. M. (1997). Insect mitochondrial control region: A review of its structure, evolution and usefulness in evolutionary studies. Biochemical Systematics and Ecology, 25(2), 99-120. https:// doi.org/10.1016/S0305-1978(96)00042-7

\section{SUPPORTING INFORMATION}

Additional supporting information may be found online in the Supporting Information section at the end of the article.

How to cite this article: Dobelmann J, Alexander A, Baty JW, et al. The association between mitochondrial genetic variation and reduced colony fitness in an invasive wasp. Mol Ecol. 2019;28:3324-3338. https://doi.org/10.1111/ mec.15159 